ELK

Asia Pacific Journals

$\underline{\text { www.elkjournals.com }}$

\title{
MICRO-FINANCE AND ITS ROLE IN DEVELOPMENT
}

\author{
Khushal Midha \\ Scholar, Indira Gandhi National Open University \\ New Delhi
}

\begin{abstract}
Microfinance is stipulation of financial facilities to lowincome peoplw. The significance of microfinance in the development field was strengthened with the commence of the Microcredit Summit in 1997. This research focuses on Potential impact of Microfinance at household and community level by providing facts and figues gathered from the available Literture on Microfinance and various summits held in context of same. The research also discusses various models of Microfinance in context of Economic Development.
\end{abstract}

Keywords: Microfinance, Economic, Development, Low income

\section{Microfinance- Definition Perspective}

Microfinance, according to Otero (1999, p.8) is "the stipulation of financial facilities to very poor self-employed and low-income poor people". The financial facilities according to Ledgerwood (1999) commonly incorporate discounts and tribute but could also incorporate other financial facilities and services like payment and insurance services. Schreiner and Colombet (2001, p.339) describe microfinance as "the challenge to develop admittance to small loans and small deposits for poor family units ignored by banks." Consequently, microfinance engages the condition of financial facilities like loans, savings, and insurance to poor and needy living in the rural and urban surroundings who are not capable to acquire such services and facilities from the official financial division.

\section{Microcredit and microfinance:}


The phrases microfinance and microcredit are frequently used identically; however it is essential to spotlight the variations between those phrases because they are often confused. Sinha (1998, p.2) declares "microcredit demotes to small loans, while microfinance is apt where MFIs and NGOs 1 increase the loans with other financial facilities (insurance, savings, etc)". Hence, microcredit is a part of microfinance in which it engages offering credit to the poor and needy, but microfinance also engages supplementary non-credit financial facilities like insurance, pensions, savings and payment facilities and services (Okiocredit, 2005).

\section{Microfinance and its history:}

Microfinance and microcredit are quite new terms in the development field, primarily coming to fame, according to Robinson (2001) and Otero (1999) in the 1970s. Preceding to subsequently, from the 1950 s to the $1970 \mathrm{~s}$, the condition of financial facilities by the governments or donors was predominantly in the structure of supported rural credit programs. These resulted often in high lose, high loan nonpayments and a lack of ability to attain rural poor family units (Robinson, 2001).

${ }^{1}$ Microfinance Institutions
Robinson declares that the 1980s symbolized a crisis in the history of microfinance in which MFIs like BRI and Grameen Bank ${ }^{2}$ started to show that they can offer savings services and small loans beneficially on a large scale. They obtained no continuing financial assistances, were profitably supported and fully maintainable, and can receive ample outreach to clients (Robinson, 2001). It was at this time in which the word "microcredit" came to fame in enhancement $\left(\mathrm{MIX}^{3}, 2005\right)$. The variation between microcredit and the financially supported rural credit agendas of the 1950s and 1960s was that microcredit claimed on refund, on costing interest rates which concealed the charge of credit delivery and by targeting on clients who were reliant on the comfortable area for credit (ibid.). It was clear now for the first time in which microcredit can offer large-scale outreach commercially.

The 1990s "saw hastened increase in the number of microfinance establishments made and an augmented prominence on achieving scale" (Robinson, 2001, p.54). Dichter (1999, p.12) demotes to the 1990s

\footnotetext{
${ }^{2}$ Bank Raykat Indonesia

3 Microfinance Information eXchange
} 
as "the decade of the microfinance". It had revolved now into a business according to Robinson (2001). With the increase in microcredit organizations, consideration transformed from just the stipulation of credit to the poor and needy (microcredit), to the stipulation of other financial facilities and services like pensions and savings (microfinance) when it grown to be clear that the deprived had a claim for these other facilities and services (MIX, 2005).

The significance of microfinance in the development field was strengthened with the commence of the Microcredit Summit in 1997. The Summit targets to achieve 175 million of the poorest families in the world, particularly the women in those families, with the recognition for the financial and self-employed and business services and facilities, by the end of $2015^{4}$ (Microcredit Summit, 2005). In recent times, the UN, as formerly declared, stated 2005 as the International Year of Microcredit.

\footnotetext{
${ }^{4}$ The initial objective was to reach 100 million people by 2005 but at the Latin America/Caribbean Microcredit

Summit in April 2005 these objectives were changed (Microcredit Summit, 2005).
}

\section{Providers and models of microfinance interventions:}

MIX states an MFI as "an institution which provides financial facilities and services to the deprived." (MIX, 2005). According to the UNCDF (2004) there are about 10,000 MFIs in this world but they only attain $4 \%$ of impending clients, concerning 30 million people. However, as of December 31st 2003, according to the Microcredit Summit Campaign Report (Microcredit Summit, 2004) the 2,931 microcredit organizations in which they have the information and data on, have accounted achieving "80,868,343 clients, $54,785,433$ of whom were the deprived when they got their loan for the time". Even if they demote to microcredit organizations, they describe that they incorporate "programs which offer credit for financial and self-employment and business facilities and services to the deprived" (Microcredit Summit, 2004). The variations between the resources spotlight many points. First of all, how the two phrases, microfinance and microcredit are confused often and utilized identically, however in the strictest sense microcredit must demote only to the stipulation of credit to the deprived. Secondly, the variation between the figures indicates 
how hard it is to get a factual picture of today how many clients they are achieving and how many MFIs are in survival. The IMF 5 declare that "no orderly and inclusive data on MFIs is gathered and there are no reliable forms on key features of the microfinance business, like the size and number of MFIs, their financial condition, or the populace provided" (2005, p.6). In spite of the lack of information and data on the area, it is very clear that a ample range of implementation processes and methods are utilized by various MFIs. The Grameen Bank (2000a) has recognized fourteen various microfinance models ${ }^{6}$ of which they will aim on three; Rotating Savings and Credit Association (ROSCAs), the Grameen and the Village Banking models, as they are the microfinance models of three in which they met at the time of field research.

\section{Credit Associations and Rotating Savings:}

\footnotetext{
${ }^{5}$ International Monetary Fund

${ }^{6}$ Associations, Bank Guarantees, Community

Banking, Co-operatives, Credit Unions,

Grameen, Group,

Individual, Intermediaries, NGOs, Peer Pressure, Rotating Savings and Credit Associations, Small Business and

Village Banking.
}

These are created when a cluster of people come along with to form normal repeated involvements to a general fund, which is then provided as a bulge amount to one member of the cluster in each and every cycle (Grameen Bank, 2000a). This representation is a familiar structure of credit and savings as stated by Harper (2002). The associates of the group are normally friends and neighbours, and the group offers a chance for social communication and are accepted in style with women. They are known Self-Help Groups or merry-grounds (Fisher and Sriram, 2002).

\section{The Grameen Solidarity Group model:}

This representation is based on group peer force any whereby loans are created to persons in groups of four to seven (Berenbach and Guzman, 1994). Group members together guarantee loan refund, and right of entry to consequent loans is reliant on flourishing refund by all group members. Payments are usually made periodical (Ledgerwood, 1999). Berenbach and Guzman (1994) stated that cohesion groups have confirmed effective and efficient in dissuading non-payments as proved by loan repayment rates achieved by institutions like the Grameen Bank, who utilize this kind of microfinance 
model ${ }^{7}$. They also spotlight the statement that this representation has added to wider social advantages due to shared trust agreement at the compassion of the group guarantee system. The group itself frequently becomes the building block to a wider social arrangement (1994, p.121).

\section{Village Banking Model:}

Village banks are said to be communitycontrolled credit and savings organizations launched by NGOs to offer access to financial facilities and services, which help members build up savings and build community self-help groups (Holt, 1994). They have been in continuation since the mid-1980s. They normally have 25 to 50 persons those who are low-income entities searching to develop their lives all the way through self-employment performance. These members manage and control the bank, choose their own officers, set up their own by-laws, allocate loans to the

\footnotetext{
${ }^{7}$ Under the Grameen Bank variation of this model, groups contain five members and savings must be

contributed for four to eight weeks prior to receiving a loan. Savings must also continue for the duration of the loan term. Only two of the group members receive a loan initially. After a period of successful repayment, twomore members receive loans and after another period of successful repayment, the final member receives a loan

(Ledgerwood, 1999).
}

people and gather services and payments (Grameen Bank, 2000a). The loans are reared by moral security; the pledge in which the group rises behind each and every loan (Global Development Research Centre, 2005). The supporting MFI provides loan principal to the village bank, who in turn provide to the members. The members mark a loan contract with the village bank to offer a collective guarantee. The members are normally asked for to keep $20 \%$ of the loan amount for each cycle (Ledgerwood, 1999). The savings of the members are tied to sum of loans and are utilized to funding new loans or group income producing deeds and so they continue within the village bank. The interest is not paid on savings but the members get a go halves of income from the village bank's re-lending performance. Several village banks aim women primarily, as according to Holt (1994, p.158) "the representation expects that participation of female members in village banks will develop status in the society and negotiating power of the intra household".

\section{Microfinance and its influence in development:}

Microfinance has played a vital role in development according to microfinance 
proponents. UNCDF (2004) declares that research analysis has shown that microfinance plays three major roles in the development area.

It:

- assists the deprived households face the fundamental requirements and prevents against risks,

- is related with enhancements in welfare of economic household,

- assists to authorize women by sustaining economic participation of the women and so encourages gender impartiality.

Otero (1999, p.10) exemplifies the different ways that "microfinance, at its Centre struggles poverty ${ }^{8} \%$. And also declares that microfinance makes access to dynamic assets for the poor, which in cooperation with human resources, tackled through training and proper education, and social resources, attained through local institution building, which enables every individual to come out of poverty (1999). By offering material resources to a deprived person, their sense of decorum is

\footnotetext{
${ }^{8}$ The concept of poverty and the impact of microfinance in combating poverty are examined in more detail in the following section of this chapter.
}

reinforced and this could assist to authorize the person to take part in the society and economy (Otero, 1999). The focus of microfinance as declared by Otero (1999) is not pretty well offering the resources to the deprived to fight poverty on an individual stage, it has a role at a societal level. It searches to form institutions which carry financial facilities and services to the poor, who are ignored continuously by the official banking sector. Littlefield and Rosenberg (2004) declare that the deprived are normally eliminated from the financial services and facilities segment of the economy so MFIs have appeared to tackle this market breakdown. By dealing with the gap in the market in an economically sustainable manner, an MFI could become division of the official financial system of a nation and so could access resource markets to subsidize their providing assortments, letting them to considerably improve the number of deprived people they could achieve Otero, 1999). In the recent times, critics like Murduch, Littlefield and Hashemi (2003), Brody and Simanowitz (2004) and the IMF (2005) have remarked on the significant role of microfinance in attaining the Millennium Development 
Goals ${ }^{9}$. Simanowitz and Brody (2004, p.1) declare, "Microfinance is a main policy in achieving the MDGs and in constructing universal financial systems which the requirements of the most deprived." Murduch, Littlefield and Hashemi (2003) declare "microfinance is a crucial related factor with strong influence on the accomplishments of the MDG. Microfinance is exclusive among enhancement interferences: it could bring social advantages on an incomplete, eternal origin and on a large scale". Demoting to different case studies, they indicate how microfinance has played a vital role in eliminating poverty, encouraging education, developing health and authorizing women (2003). On the other hand, not all critics are as passionate regarding the role of microfinance in improvement and it is essential to recognize that microfinance is not a silver bullet when it comes to struggling poverty. Hulmeand Mosley (1996), as recognizing

\footnotetext{
${ }^{9}$ The MDGs are (i) eradicate extreme poverty and hunger; (ii) achieve universal primary education; (iii) promote

gender equality and empower women; (iv) reduce child mortality; (v) improve maternal health; (vi) combatHIV/AIDS, malaria and other diseases; (vii) ensure environmental sustainability; and (viii) develop a global

partnership for development (Littlefield, Murduch and Hashemi, 2003).
}

the role microfinance could have in assisting to eliminate poverty, terminated from their study on microfinance which "most current proposals are less effective and efficient than they may be" (1996, p.134). They declare that microfinance is not a universal remedy for povertyelimination and which in some cases the deprived people have been created worseoff by microfinance. Rogaly (1996, p.109/110) identifies five main blunders with MFIs. The author argues that:

$>$ they promote a single-sector approach to the allotment of capital to fight against poverty,

$>$ microcredit is inappropriate to the deprived people,

$>$ an over-unsophisticated concept of poverty is utilized,

$>$ there is an over-stress on scale,

$>$ there is insufficient learning and amend taking place.

Wright (2000,p.6) declares that much of the uncertainty of MFIs stalks from the disagreement in which microfinance schemes "fail to achieve the deprived, normally have a restricted outcome on income force women into better belief on their husbands and fail to give extra services greatly required by the poor and needy". Additionally, Wright tells that 
several enhancement consultants not only identify microfinance insufficient, but that it essentially deflects funding from "more depressing or significant interferences" like education and health (2000, p.6). According to Navajas et al (2000), there is a hazard in which microfinance might drain off funds from other schemes which may assist the deprived people more. They declare that donors and governments must recognize whether the deprived achieve more from microfinance, than from more food aid or health care for instance. Hence, there is a necessitate for all engaged in microfinance and enhancement to determine what actually has been the influence of microfinance in reducing poverty. Substantial ponder stays regarding the efficiency of microfinance as a device or openly eliminating poverty, and about the features of the people it advantages (Chowdhury, Mosley and Simanowitz, 2004). Sinha (1998) states that it is extremely very hard to determine the influence of microfinance poverty programs. The author argues, because wealth is fungible and hence it is very hard to segregate credit influence, but also due to the definition of 'poverty', how it is determined and who comprise the 'poor' "are brutally disputed problems" (1998, p.3).Poverty is a multifaceted issue and is very hard to state, as there are different dimensions to poverty. Forsome, like World Bank, poverty associates to income, and poverty evaluates are based on the proportion of people living under an unchanging sum of money, like US\$1 dollar a day (World Bank,2003).

\section{The influence of microfinance on poverty:}

There is a firm amount of debate about whether influence appraisal of microfinance schemes is essential or not as stated by Simanowitz (2001b). The disagreement is that if the market could offer sufficient proxies ${ }^{10}$ for influence, indicating that clients are very glad to pay for a service or facility, appraisals are a waste of sources (ibid.). On the other hand, this is too crude a underlying principle as market proxies mask the variety of client replies and advantages to the MFI (ibid.) hence, the effect appraisal of microfinance interferences is essential, not just to show to donors in which their interferences are having a positive influence, but to permit for learning within MFIs so that they could develop their services and the effect of their projects (Simanowitz, 2001b, p.11).

\footnotetext{
${ }^{10}$ Such as good client retention and repayment rates.
} 
Poverty is said to be a lack of income. Wright (1999) spotlights the deficiencies of aiming merely on improved income as an assess of the influence of microfinance on poverty. The author declares that there is a major difference between improving income and eliminating poverty (1999). The author states that by improving the income of the poor, MFIs are not inevitably eliminating poverty. It depends upon what the poor people do with the money, oftentimes it is ventured away or wasted on alcohol (1999), so targeting merely on improving incomes is not sufficient. The target requires to be on assisting the deprived to "maintain a specified level of comfort" (Wright, 1999, p.40) by providing them a range of financial services and facilities tailored to their requirements so that their income security and network wealth could be increased. It is frequently declared which MFIs are not achieving the deprived in society. On the other hand, even with some critics' disbelief of the influence of microfinance on poverty, research analysis have indicated that microfinance has been thriving in various situations. Littlefield, Murduch and Hashemi(2003, p.2) declares that "several studies...document improves in assets and income, and reduces in susceptibility of microfinance clients".
They demote to projects in the countries like India, Zimbabwe, Bangladesh, Indonesia, and Uganda which all indicate very positive influences of microfinance in eliminating poverty. For example, a report on a SHARE project in India indicated that three-quarters of clients saw "essential developments in their economic happiness and that half of the clients accommodated out of poverty" (2003, p.2).Dichter (1999, p.26) declares that microfinance is a device for poverty elimination and when arguing that the evidence of MFIs in microfinance is "normally well below the anticipation" the author does compromise that some positive influences do take place. A number of MFIs, from a study the author declares that results indicate that expenditure smoothing effects, marks of redeployment of wealth and effect within the family are the most common influence of MFI programs (ibid.).Hulme and Mosley (1996, p.109) argued in a comprehensive study on the utilization of microfinance to conflict against poverty, that elegant programs could increase the incomes of the deprived and could take them out of poverty. They declare that "there is clear data that the influence of a loan on a borrower's income is associated to the range of income" as those with superior incomes have a better variety of 
venture of chances and so credit plans are more liable to advantage the "upper and middle poor" (1996, pp109-112). On the other hand, they also indicate that when MFIs like the BRAC and Grameen Bank offered credit to deprived families, those households were capable to elevate their profits and their advantages (1996, p.118).

Mayoux (2001, p.52) states that while microfinance has much potential ${ }^{11}$ the major outcomes on poverty have been:

$\checkmark$ credit building an essential involvement to improving incomes of the comfortable poor, incorporating women,

$\checkmark$ microfinance services and facilities adding to the flattening out of heights and trenches in income and expenses thus enabling the poor to deal with changeable emergencies and astonishments.

\footnotetext{
${ }^{11}$ (i) to smooth out peaks and troughs in income and expenditure; (ii) to invest in businesses/assets including new technology, capital and assets such as land or housing; (iii) to cope with unpredictable shocks and

emergencies such as death and natural disasters; (iv) to make socially required contributions to lifecycle or

community events like marriages, funerals and religious festivals (Mayoux, 2001).
}

Hulme and Mosley (1996) indicate that when loans are related with a growth in resources, when borrowers are persuaded to provide in low-risk profit producing deeds and when the very poor are motivated to keep and save; the susceptibility of the very poor is eliminated and their poverty condition increases. Johnson and Rogaly (1997, p.12) also demote to illustrations whereby credit and savings schemes were able to face the requirements of the deprived. They declare that microfinance specialists are stating to view developments in economic safety, quite income endorsement, as the first step in poverty elimination (ibid.) as this eradicates beneficiaries' overall susceptibility.

Thus, while much debate stays about the influence of microfinance projects on poverty, they have seen that when MFIs accepts the requirements of the deprived and try to face these requirements, projects could have a positive influence on eliminating the susceptibility, not just of the poor, but also of the deprived in society. Present debates on the influence of microfinance in enhancement.

\section{Microfinance and Livelihood security:}


Carney (1998, p.4) states a living as encompassing "...the assets, abilities, (incorporating the social resources and materials) and deeds needed for a means of livelihood." Chambers (1997, p.10) states that livelihood safety is "basic to happiness or comfort" and which safety "demotes to sheltered rights and dependable admittance to capital, income, food and fundamental services. It incorporates substantial and insubstantial assets to balance risk, ease meet contingencies and shocks "Lindenberg (2002, p.304) states living safety as "a community's or household's capability to sustain and develop its assets, income and social comfort from year to year." Anxiety also declare that living safety is more than just economic happiness as they state livelihood security as "the ample and sustainable access to and manage over capital, both social and material, to allow families to attain their rights without challenging the natural capital base" (Concern, 2003). Living security hence, such as poverty, is not just about the income or resources, but incorporates substantial and insubstantial assets, and social happiness.

Johnson and Rogaly (1997, p.122) declare that "NGOs focusing for poverty elimination require to measure the influence of their services and facilities on the livelihoods of the users". They argue (1997) that in dealing with the question of the influence of microfinance, NGOs should exceed analyzing quantitative data detailing the numbers of users, and size and volumes of loans distributed, to accepting how their projects are influencing on the livelihoods of the clients'. They declare (1997, p. 118) that the stipulation of microfinance could give poor people "the means to protect their livelihoods against shocks as well as to build up and diversify their livelihood activities". Thus when analyzing the influence of microfinance the overall influence of the microfinance services and facilities on the livings of the deprived requirements to be carried out into deliberation. A living security approach as stated by Concern (2003) focuses for a holistic analysis and accepting of the core causes of the poverty and how people tackle poverty. They find livelihood shocks like drought and natural disasters, the political, social and economic perspective, and people's livelihood sources like local infrastructure and education as factors and issues influencing people's livelihood security (ibid.). Hence, when analyzing the influence microfinance 
is having on livelihood security, as is the objective and goal of this thesis, an holistic analysis of the livelihood security of the people should be performed, quite targeting on the economic/material influence microfinance is having on the livelihoods of the deprived.

\section{Social impact analysis:}

Conventionally, the influence of the projects of microfinance was measured by the amends in the income or support of the clients. Mansell-Carstens, quoted in Rogaly (1996, p.103) declares that such a target is defected because the respondents may provide forged information. It is very hard to determine all the sources of client's income, so a fundamental cause is hard to ascertain, and it is very hard to ascertain what would have occurred if the loan was not provided. Hence a wider analysis is required in which it takes more than economic influence into deliberation. They have seen that livelihood security and poverty consist of the social and economic situations, hence, when analyzing the influence of microfinance, and social influence should be measured. Kabeer (2003, p.106) declares that broader social influence appraisal is essential for an institution's inner learning process and method, as an MFI must be attentive of the "full variety of amends related with its attempts and uses these to develop its presentation". The author believes social influence to associate to human resources like health, nutrition, and education, and social systems (2003). Influence should be measured on each of these factors and issues if a factual picture of the influence of microfinance is to be attained. On the other hand, Kabeer progresses ahead of household or individual analysis to declare that analysis must also be performed at the center of population, economy/market and state/national levels (2003). The author refers to these as "areas of influence" because societies are encompassed of various institutional areas each and every with their own rules and regulations, practices and norms which could be effected by microfinance interferences in various ways(2003, p.109). Kabeer (2003, p.110) not only demotes to areas of influence but also spotlights the dimensions of change which must be measured. The author registers cognitive change ${ }^{12}$, change of the behaviour ${ }^{13}$, material Change ${ }^{14}$, relational change ${ }^{15}$

\footnotetext{
${ }^{12}$ Changes in the way in which people understand and make sense of the world around them.

${ }^{13}$ The different types of actions that people undertake in order to achieve their goals ${ }^{14}$ Changes in access to a variety of tangible resources.
} 
and institutional change 16 as measurements of change which require to be carried out into account if the broader influences of microfinance interferences are to be accepted. Zohir and Matin (2004, p.301) create a similar point when they declare that the impact of microfinance involvements is being under-evaluated by "conventional influence studies which do not consider to be the potential positive externalities on spheres beyond families". They recommend that the influence must be investigated from economic, social cultural and political areas at enterprise, individual, and household ranges (2004).McGregor et al. (2000, p.3) declares that broader economic and social influences could happen through the capital market, the labour market, the market for goods and services consumed by the deprived people, through fabrication linkages and through participation of the clients in political and social processes and methods. Chowdhury, Mosley and Simanowitz (2004) state that if microfinance is to satisfy its social goals and objectives of

\footnotetext{
${ }^{15}$ Changes in the terms on which people interact with one another.

${ }^{16}$ Changes in the rules, norms and behaviour at an institutional level.
}

upcoming financial services and facilities to the deprived it is essential to understand the extent to which its broader influences add to poverty elimination.

\section{Impacts at a household level:}

Education and health are two main areas of non-financial influence of microfinance at a family level. Wright (2000, p.31) declares that from the little research that has been conducted on the influence of microfinance involvements on education and health, nutritional pointers seem to develop where MFIs have been engaging. The research on the Grameen Bank indicates that members are arithmetically more liable to utilize contraceptives than non-members thus influencing on family size (ibid.). Littlefield, Murduch and Hashemi (2003, p.3) also recognize the meagre particular proof of the influence of microfinance on health and education but where studies have been performed they terminate, "families of microfinance clients emerge to have higher nutrition, health education and health practices than similar non-client families". Among the illustrations they provide is of FOCCAS, a Ugandan MFI whose clients were provided health care tutoring on family planning and breastfeeding. They were seen to have much higher health care practices and 
activities than non-clients, with $95 \%$ of clients employed in developed nutrition and health practices and activities for their children, as resisted to $72 \%$ for non-clients (Littlefield, Murduch and Hashemi, 2003).Microfinance involvements have also been indicated to have a positive influence on the education of children of the clients. Littlefield, Murduch and Hashemi (2003, p.4) declare that one of the first things in which the deprived people do with new income from microenterprise deeds is to spend in the education of their children. Some studies indicate that children of microfinance clients are more liable to go to school and reside longer in school than for the nonclients' children. Once more, in their research of FOCCAS, client families were identified to be spending more in education than non-client family circles. Related results were seen for projects in India, Honduras, Zimbabwe, and Bangladesh (ibid.).Robinson (2001) in a study of 16 various MFIs from all over the world indicates that having admittance to microfinance services and facilities has led to a development in the eminence of life of clients, a growth in their self-confidence, and has assisted them to spread their livelihood security strategies and factors and in this manner improve their income.
Pursuing a three-year study with 906 clients, ASA ${ }^{17}$ an MFI engaging with 60,000 of women of the rural area in Tamil Nadu, India, identified that their project had several positive influences on their clients (Noponen, 2005). The agenda was having a "positive influence on social status, livelihoods, treatment in the community and home, the conditions of the livelihood and expenditure standards" (2005, p.202). Balanced with new clients, some of the results indicated that longterm members were more liable to live in concrete houses and overlay roofed and, to have a better percentage of their children in school, to have lower occurrence of child labour, to be the greatest income giver or joint giver in the home and community, and to take resolutions on their own as regards main acquisitions (Noponen, 2005). Members also replicated important increases in the livelihood ownership assets like equipment, livestock and land (ibid.).

In 2002, FINRURAL, a microfinance networking administration in Bolivia, taken out influence appraisals on eight of its partner MFIs aiming on social and economic impacts at an individual, community and household level on the

${ }^{17}$ Activists for Social Alternatives 
clients and non-clients (Marconi and Mosley, 2004). Several influences on income were positive for the less poor and negative for the poorer clients, a tendency that they have seen already. Marconi and Mosley (2004) declare that this must not be surprising as poorer clients are more risk unpleasant and less likely to spend in fixed resources and so are more susceptible to having to sell dynamic possessions in the event of a shock. On the other hand, it was identified that social and economic networks played a vital part in assisting clients escape from poverty. Admittance to social networks offered clients with a resistance against having to sell human and physical assets and so protected family unit advantages (ibid.).Chowdhury and Bhuiya (2004, p.377) measured influence of BRAC's poverty elimination programme from a "human happiness" viewpoint in a programme in Bangladesh where they investigated seven measurements of 'human-comfort' 18 . The project incorporated the stipulation of microfinance and training of clients on

\footnotetext{
${ }^{18}$ Increased income, improved women's lives, control over fertility, sustainable environment, decreased

mortality, decreased morbidity and increased nutritional status (Chowdhury and Bhuiya, 2004, p.377)
}

legal and human rights (ibid.). They quoted that the project led to better child endurance rates, greater nutritional status, development in the basic level of education, and improved networking in the society. The children of BRAC clients endured from far less protein-energy undernourishment than children of nonmembers, and the educational act of BRAC member's children was also greater than that of children in non-BRAC families (ibid.). BRAC member households spent importantly more on expenditure of food items than poor nonmembers did and per head calorie ingestion was also importantly greater. Thus, different studies and results show that microfinance could, and is having very positive and different influences at a beneficiary level.

\section{Empowering Women:}

A main objective and goal of several microfinance intrusions is to give power to women. Mosedale (2003, p.1) declares that if they want to look people empowered it means they recently notice them as being disadvantaged, disempowered, by the way power relationships figure out their selections, comfort and opportunities. The author declares that empowerment could be conferred by a third party but should be 
argued by those searching empowerment through a fragmentary process of manifestation, action and analysis (2003).Kabeer, stated in Mosedale (2003, p.2) declares that women require empowerment as they are restricted by "the norms, customs, beliefs and values through which societies differentiate between women and men". The author also declares that empowerment refers to the "process by which those who have been refused he capability to create strategic life options obtain such an ability", where strategic options are "crucial for people to live the lives they want (Kabeer, 1999, p.437). Therefore MFIs cannot empower women openly but could assist them through education and training and awareness-raising to challenge the surviving norms, values and cultures which place them at a disadvantage in relation to men, and to assist them have higher control over capital and their lives.

Littlefield, Murduch and Hashemi (2003, p.4) state that access to MFIs can empower women to become more confident, more assertive, more likely to take part in family and community decisions and better able to confront gender inequities. However, they also state that just because women are clients of MFIs does not mean they will automatically become empowered. Hulme and Mosley (1996, p.128) also make this point when they refer to the "naivety of the belief that every loan made to a woman contributes to the strengthening of the economic and social position of women". However, with careful planning and design women's position in the household and community can indeed be improved. According to Littlefield, Murduch and Hashemi (2003), the Women's Empowerment Program in Nepal found that $68 \%$ of its members were making decisions on buying and selling property, sending their daughters to school and planning their family, all decisions that in the past were made by husbands. They refer to studies in Ghana and Bolivia, which indicated that women involved in microfinance projects, had increased selfconfidence and had an improved status in the community (ibid.).Hulme and Mosley (1996) state that microfinance projects can reduce the isolation of women as when they come together in groups they have an opportunity to share information and discuss ideas and develop a bond that wasn't there previously. From studies of the Grameen Bank and BRAC they show that clients of these programmes suffered from significantly fewer beatings from their husbands than18 Increased income, 
improved women's lives, control over fertility, sustainable environment, decreased mortality, decreased morbidity and increased nutritional status (Chowdhury and Bhuiya, 2004, p.377they did before they joined the MFI (ibid.). However, in a separate study of a BRAC project Chowdhury and Bhuiya (2004, p.383) found that violence against women actually increased when women joined the programme, as not all men were ready to accept the change in power relations, and so resorted to violence to express their anger. This violence did decrease over time. The study found that when the violence did rise, the members, because of their increased awareness, reported back to the group on their martial life and got support from the group (ibid.).Jeffery Sachs (2005) in a visit to a BRAC project was amazed to find that women he spoke to had only one or two children, when he was expecting them to have five or six as he had become accustomed to for Bangladeshi women. When he asked those with no or one child how many children they'd like to have, the majority replied two. He calls this a "demonstration of a change of outlook" (2005, p.14). He refers to a new spirit of women's rights, independence and empowerment among clients, showing the positive empowerment effects the project has had on the women (ibid.).Osmani (1998) analysed the impact of credit on the well beingn ${ }^{19}$ of Grameen Bank women clients. The project was found to have increased their autonomy in that they were able to spend family income more freely than nonclients. They had greater control over family planning, but the project was not shown to have had an impact on clients' control over other decision-making but they were found to have greater access to household resources than non-clients did. However, Johnson (2004, p.5) states that having women as key participants in microfinance projects does not automatically lead to empowerment, sometimes negative impacts can be witnessed. She refers to increased workloads, increased domestic violence and abuse. This leads her to ask a crucial question of whether targeting women is just an efficient way of getting credit into the household, since women are more likely than men to be available in the

\footnotetext{
${ }^{19}$ Women's well-being is defined in terms of three sets of capabilities: (i) the degree of autonomy with which

women can live their lives, (ii) their ability to control decision making within the family and (iii) their relative education, etc. (Osmani, 1998, p.31)
} 
home, attend meetings, be manageable by field staff and take repayment more seriously, even if they do not invest or control the loan themselves? Or on the other hand, if such targeting is fully justified on the grounds of enhancing gender equity. She claims the answer is probably somewhere between the two alternatives (ibid.). She argues that MFIs must analyse both the positive and negative impacts their interventions are having on women, and that MFIs need to work with men to help pave the way for a change in attitudes to women's enhanced contribution to the household (2004, p.6).

\section{Impacts beyond the household:}

In this study, several findings that indicate the positive impacts microfinance interventions could have beyond client households. Imp-Act (2004b) gives examples where the impact of microfinance projects goes beyond clients. They refer to studies on CERUDEB, an MFI in Uganda, which show that loans given to small farmers have resulted in substantial increases in part-time and permanent wage labour of non-clients (ibid.). Even though the clients themselves were usually above the poverty line, the people they employed were not, thereby showing the positive knock-on effects of such an intervention, even if the poorest were not targeted. Mosley and Rock (2004, p.467) in a study of six African MFIs found similar results. They concluded from their study that MFI services provided to the non-poor can reduce poverty by "sucking very poor people into the labour market as employees of microfinance clients". They also state that microfinance services often enhance human capital through increased spending on education and health that may extend to poor households through intra household and inter-generational effects (ibid.).Zohir and Matin (2004, p.318) state that many MFI loans are used for agricultural production, trading, processing and transport, resulting in an increase in the use of agricultural inputs and increased output of agricultural production. This leads to enhanced employment opportunities in these sectors for the wider community and a reduction in the prices of such produce due to increased supply. They also state that trading activities financed by MFIs can help to establish new marketing links and increase the income of traders, and this can lead to reduced migration due to increased employment opportunities and increased income (Zohir and Matin, 2004). From a social perspective, they state that reduced migration increases family cohesion and 
greatly contributes towards improving child-upbringing (ibid.).Kabeer (2003, p.110) refers to a study conducted by the Grameen Bank which showed that nonmembers of a Grameen village were significantly more likely to use contraception than non-members in a nonGrameen village. This was due to a diffusion of the "small family norm" of Grameen women through social networks within the village as the Grameen Bank emphasises women's productive roles, as opposed to their reproductive role, and non-members picked up this norm from members. Studies have also shown that Grameen-style projects, based on collective activism, can lead to a greater level of legal and political awareness among clients, with a greater likelihood of clients taking part in political campaigns the longer they had been a member (Kabeer, 2003, p.111).Zohir and Matin (2004) state that the interaction within MFI groups can create co-operation and trust that not only facilitates the microfinance activities, but also contributes benefits beyond the service provided, such as a greater sense of community, trust and reliance on the group in times of crisis. These networks can lay the foundations for other social capital developments in the community. They state that examples of cultural impacts of social intermediation that affect the greater community could be a change in approach of society towards the understandable age of women's marriage, dowry, domestic violence, etc. (ibid.).

Hence, the impact of microfinance schemes must not just aim on the household and individual levels if the true impact is to be considered. Microfinance could have a far broader impact than the household level, as shown in Figure 1(Refer figure 1 here), and this should be considered if a true illustration of microfinance projects is required.

\section{The use of the Sustainable Livelihoods Framework in impact measurement:}

Microfinance could have a vast range of impacts on households and individuals engaged in the project, but this could also have broader social and economic impacts. Many ways are there to measure the impact like by using AIMS ${ }^{20}$ toolkit (Simanowitz, 2001c), Social Performance

\footnotetext{
${ }^{20}$ Assessing the Impact of Microenterprise Services - uses household surveys, client exit surveys, loan/savings

use tools and focus group discussions on client satisfaction and empowerment (Simanowitz, 2001c).
} 
Assessments (SPAs) (Copestake, 2004), and Internal Learning Systems (Noponen, 2005). Most of the measurements use quantitative research devices like financial ratios and participatory tools, surveys and qualitative tools like participant observation and focus group discussions (Simanowitz, 2001c). This study is aimed on the impact of microfinance on livelihood security. Hussein (2000, p.5) declares that a livelihoods impact measurement spotlights the need to know the importance of a project to the livelihoods of project beneficiaries and the local people. This is the main aim of this dissertation. Simanowitz (2001b, p.17), declares that impact assessment should be based on a "sound conceptual framework which could be utilized for improving hypothesis about possible impact channels, and as a framework for analysis and for better understanding. Specifically useful is a livelihoods analysis which assists contextualise specific interferences in a wider understanding of poverty". According to Neefjes (2000, p.82) a livelihoods framework is "people centred and aims to explain the relationships between people, their livelihoods, (macro) policies and all kinds of institutions." Brocklesbyand Fisher (2003, p.187) explain the four main components of the livelihoods framework, as used by DFID ${ }^{21}$ which has been widely adopted in the development field. These are:

- people reside within a vulnerability context i.e. they are exposed to risks like sudden shocks,

- seasonal change and trends over time;

- people have a many resourceful assets $^{22}$ in which they draw upon to make their livelihoods;

- these benefits are drawn upon within people's livelihood strategies;

- institutions policies, and processes which assist to shape people's benefits, livelihood activities and the

- vulnerability context in which they survive.

Carney (1998) declares that an examination of the five resource assets provides a holistic analysis of people's livelihoods. These resource assets form the centerpiece of people's livelihoods as these assets dictate the level of vulnerability of beneficiaries to shocks and trends. Policies and institutions also have

\footnotetext{
${ }^{21}$ Department for International Development ${ }^{22}$ Financial capital, physical capital, human capital, natural capital and social capita.
} 
an impact on these assets. These policies and institutions, and beneficiaries' own vulnerability context influence their livelihood strategies which in turn dictate their livelihood outcomes as indicated in Figure2 (ibid.)(Refer figure 2 here). IDS (2004) also declares that such a framework allows examination into the ways in which a project openly and ultimately influences people's livelihoods. This framework thus will be used in this research to consider the impact of microfinance on the beneficiaries' livelihoods by aiming on its impact on their five capital assets.

\section{Current debates about MFIs and}

\section{their role in development:}

When examining the impact microfinance has on livelihood security and poverty it is important to be aware of the current debates that are taking place in the field of microfinance. One of those debates, as we have seen, is on impact measurement. However, there are two other major issues that will be examined in this section of the study, reaching the poor and financial sustainability.

\section{Reaching the Poor:}

As highlighted, one of the key roles microfinance has to play in development is in bringing access to financial services to the poor, to those who are neglected by the formal banking sector. This is their social mission. Mainstream banks target clients that have collateral. The poor do not have assets to act as collateral, therefore they are ignored by the formal financial sector. These banks tend to be found in urban centers while the majority of the poor in the developing world live in rural areas, where financial services are not provided. Therefore, if MFIs are to fill this void they must reach the rural poor. However, according to most studies, microfinance is only reaching a small fraction of the estimated demand of the poor for financial services (Littlefield and Rosenberg, 2004).MFIs do not have the depth of outreach that is needed to meet the demands of the rural poor. Serving the rural poor in the developing world involves a major financial commitment, as it is expensive to run rural microfinance projects. Claessens (2005) states that high transaction costs, small volumes and the high costs of expanding outreach, make it unprofitable to serve the rural poor. It is for this reason that commercial banks are positioned in areas of high population density. However, if MFIs are to meet their social mission of serving the poor then financial services need to reach the 
rural poor. Another common criticism of the current operational procedures of MFIs, for instance, peer group selfselection and the drive for selfsustainability, is that they end up working with the moderately poor, and marginalising the poorest of the poor. Simanowitz (2001a, p.5) highlights a number of factors leading to the marginalisation of the poorest, which lessens the impact microfinance is having on poverty; self-exclusion ${ }^{23}$, exclusion by other members ${ }^{24}$, exclusion by MFI staff ${ }^{25}$ and exclusion by design ${ }^{26}$.Markowski (2002) and Rogaly (1996) argue that MFIs in their project designs are failing to meet the needs of the very poor and destitute, who do have a demand for microfinance services, especially for savings (Littlefield and Rosenberg, 2004 and Dichter, 1999). They are ignored, yet an objective of the

\footnotetext{
${ }^{23}$ Many poor people do not see microfinance projects as being relevant or beneficial to them. ${ }^{24}$ In group-based lending in particular there can often be an incentive for stronger people in the community to

exclude the very poor, especially when group guarantee systems are in place.

${ }^{25}$ Loan officers may have incentives to exclude the poorest if they see them as problematic, as increasing their

workload or impacting on their sustainability targets.

${ }^{26}$ The design of services may exclude the poorest e.g. having entry fees and inappropriate loan terms
}

Microcredit Summit is to reach 175 million poor people by 2015 but MFIs do not seem to be on target for meeting this objective.

Organisations such as BRAC with their IGVGD $^{27}$ and CFPR $^{28}$ programmes have shown that the poorest people can be targeted in a sustainable manner (Halder and Mosley, 2004). Johnson and Rogaly(1997) state that some features of savings and credit schemes are able to meet the needs of the very poor. In relation to reaching those living in extreme poverty, Littlefield, Murduch and Hashemi (2003,p.5) refer to a study of 62 MFIs that have reached full financial self-sufficiency with 18 MFIs that targeted what they defined as "the poorest clients" averaging better profitability than the others. This shows that when properly managed, programmes that target the very poor can become financially sustainable. The onus is therefore on other MFIs to develop products and services that will meet the needs of the very poorest if the social mission of microfinance is to be achieved. MFIs therefore need to improve their depth and breath of outreach. They must design appropriate products based on the needs of

\footnotetext{
${ }^{27}$ Income Generation for Vulnerable Group Development

${ }^{28}$ Challenging the Frontiers of Poverty
} 
the poorest and they must ensure such products are delivered in a cost-effective manner (Simanowitz with Walter, 2002).

\section{Financial sustainability versus serving the poor:}

MFIs have more than just a social mission. Markowski (2002, p.117) states they have a dual mission: asocial mission " to provide financial services to large numbers of low-income persons to improve their welfare", and a commercial mission "to provide those financial services in a financially viable manner".

We have already seen that MFIs are not fulfilling their social mission to the extent needed to meet the demands of the poor for financial services. Simanowitz with Walter (2002) argue that microfinance is a compromise between this social mission and commercial mission. As there is more emphasis on financial and institutional performance, opportunities for maximizing poverty impact and depth of outreach have been compromised. They call for a balancing of social and financial/commercial objectives because the current focus on financial objectives means fewer of those most in need of microfinance services are being targeted. To do this they argue "it is now time to innovate and design services that maintain high standards of financial performance, but which set new standards in poverty impact" (2002, p.3).Markowski (2002) states that $\mathrm{CGAP}^{29}$ estimates that only about $5 \%$ of MFIs worldwide are financially sustainable while the IMF (2005) puts the figure at only $1 \%$, so this is a huge issue for the microfinance sector. To achieve financial sustainability according to Havers (1996), an MFI must cover the cost of funds, operating costs, loan write-offs and inflation with the income it receives from fees and interest. According to the IMF (2005) the MFIs that have become self-sustainable tend to be larger and more efficient. They also tend not to target the very poor, as targeting the less poor leads to increases in loan size and improved efficiency indicators, whereas MFIs focusing on the poorest tend to remain dependent on donor funds (IMF, 2005). This is where the compromise exists. In order to achieve such sustainability, while at the same time reaching those most in need, microfinance programmes need to be managed in a

\footnotetext{
${ }^{29}$ Consultative Group to Assist the Poor - a multi donor effort of 25 western donor countries and international

agencies formed by the World Bank to address the problems facing microfinance (Grameen Bank, 2000b).
} 
rigorous and professional manner, subsidises must be removed ${ }^{30}$, and tight credit control procedures and follow-up on defaulters needs to be in place (Havers, 1996). There is no doubt that sustainability is also very important from clients' perspectives, as they place a high value on continued access to credit, and if they feel that the MFI will not survive it reduces their incentive to repay loans (Von Pischke, 1999).Appropriate loan sizes for clients matching their needs, realistic interest rates, savings as a prerequisite, regular, short and immediate repayment periods and achieving scale can contribute to sustainability (Havers, 1996). If these measures to achieve sustainability are put in place, while focusing on the needs of the poorest, then both the social and financial objectives can be achieved. In simple terms, the tradeoff between financial and social objectives can be balanced if the MFI is well managed and understands the market and its clients (Morduch, 2004) and by combining both objectives, financial returns can potentially be increased in the long run (Pawlak and

\footnotetext{
${ }^{30}$ Subsidies create incentives for the capture of funds by those who are better off and therefore better able to gain

access to the funds because of their social, economic and political status (Von Pischke, 1999).
}

Matul, 2004). Imp-Act (2004a) states it when assessing the performance of an MFI, both its financial and social performance must be assessed, as both are needed for the successful running of an MFI. Simanowitz, quoted in Imp-Act (2004a) refers to this as an MFI's “double bottom line". As stated by Morduch "achieving profitability and strong social performance is the ultimate promise of microfinance. It is not impossible but neither is it easy" (2004a, p.3) and this is the challenge facing all MFIs. Hence the recent challenges meeting MFIs are threefold, it concerns, not only, financial sustainability, but also outreach extending the services to greater numbers of the deprived, and depth of outreach trying to reach the deprived members of society.

\section{Conclusion:}

In this study they have reconsidered the development of microfinance over the past thirty years and investigated in brief three of the MFI models which survive in the present time. The role of MFIs in improvement, particularly in relation to eliminating poverty was also investigated. The main challenges facing MFIs at present which are influencing their impact on poverty reduction were seen to be an 
over-emphasis on economic sustainability over social and economic objectives and goals, and a breakdown of several MFIs to work with the deprived in the society. Hence, there is a higher requirement for MFIs to cautiously design services and facilities which face the requirements of the poor and this could only be done when MFIs know their requirements and the circumstance within which the poor are employing (Morduch, 2004).If MFIs are to face their overall improvement objectives and goals then they have to make sure that financial sustainability and outreach of financial facilities and services designed to face the needs and requirements of those most in need of such services. The influence of microfinance on poverty reduction is a observed and keenly debated factor as they have seen and it is normally understood that it is not a silver bullet, it has not lived up generally to its anticipation (Hulmeand Mosley, 1996). On the other hand, when implemented and controlled cautiously, and when services and facilities are structured and designed to face the needs of clients, microfinance has had impacts positively, not just on clients, but on their households and on the broader society. There is still a requirement for higher appraisal of these broader impacts if the true value of microfinance to improvement is to be known (Zohir and Matin,2004). One such device for assessing broader impact is a livelihood security analysis based on a living framework that analyses how a project impacts on the livelihoods of beneficiaries. 
List of figures:

Fig. 1. Potential impact of microfinance at a household and community level:
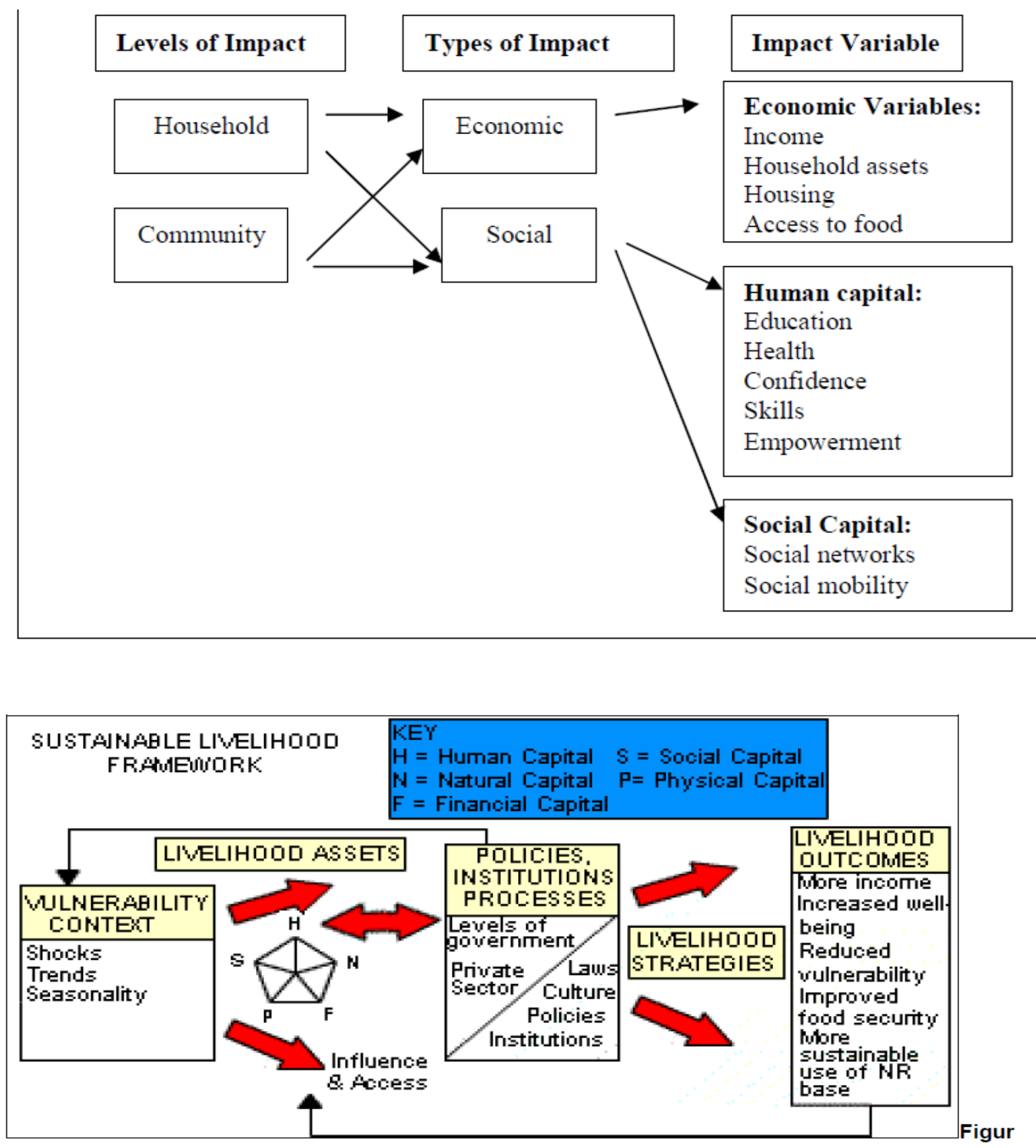

fig. 2. Sustainable Livelihood Framework.

Taken from DFID Sustainable Livelihoods Guidance Sheets, Section Two. 